\title{
Sociocultural Byzantine Influence on Thought Formation in Medieval Russia
}

\section{PAVEL REVKO-LINARDATO / Taganrog /}

Then we went among the Germans, and saw them performing many ceremonies in their temples; but we beheld no glory there. There we went on to Greece, and the Greeks led us to the edifices where they worship their God, and we knew not whether we were in heaven or on earth. For on earth there is no such splendor or such beauty, and we are at a loss how to describe it. We know only that God dwells there among men, and their service is fairer than the ceremonies of other nations. For we cannot forget that beauty.

The Russian Primary Chronicle

Повпоть времлньныхь льть

\section{Specific Character of Byzantine Sociocultural Influence on Eastern Slavs}

The Byzantium and Eastern Slavic interrelation was a key factor which in the medieval Russia predetermined specific development of various branches of culture including but 
not limited to the Orthodox Church, theology and philosophy. That is why a discrete role in understanding specific character of historical ways of Russian, Ukrainian and Byelorussian (at that time of the Grand Duchy of Lithuania - Вялікае Княства Літоўскае) cultures lies in bringing to light the forms of implementing therein Byzantine philosophic traditions. Herewith it is advisable to contemplate the philosophy within the context of general historical realities as a specific cultural life element. In this regard, the definition of the Byzantine cultural influence on formation of philosophic thought in the medieval Russia seems to be highly relevant.

Expansion onto neighbouring nations of Byzantine cultural influence including elements of scientific and philosophic experience had an active and a purposive character and first of all was induced by the interest to subordinate neighbouring state and pre-state formations to ecclesiastical and political power of the Empire. The Byzantine influence on other nations manifested itself erratically and with a different intensity in various cultural spheres. In some cases it deeply penetrated cultures of different nations and in other cases the influence remained superficial and it only formed a thin layer on the top of existing local traditions. It should be noted that the problem of defining the essence and the specific character of the Byzantine influence on the Eastern Slavs is of a polemical character. It seems to be necessary to avoid both the attitude which idealizes significance of the Byzantine cultural tradition and which proclaims its implicitly favourable influence and the attitude which diminishes subject matter of the Byzantine heritage and even proclaims its negative role. The attention should be focused not so much on the Byzantine influence as such but as on its selective and contradictory nature of its adoption by the Russian, Ukrainian and Byelorussian cultures.

The Eastern Slavic pagan world view which had been formed under the influence of geographic peculiarities of their places of residence was an original basis which the Byzantine influence was superimposed on. By the ninth century the pagan world view which could not interrelate with the world views of monotheistic religions adopted around Russian territories, became a significant obstacle on the way of foreign cultural ties and adoptions including the ones in the sphere of science and industrial arts. Thanks to adoption of Christianity the Old Russian state implemented modernization of the Slavic pagan world view. The most important effect of the introduction of Christianity into Russia became a new world view formation which by its character was neither pagan nor Christian but consisted of their fragments. The Kievan Rus world view was not and could not become a duplicate of the Byzantine world view because the world view change was never implemented as a physical replacement of old symbols with new ones but happens due to interrelation of new ideas and the retained old ones in their mutual transformations. It helps to remember that the Byzantine world view was a result of a peculiar synthesis of antique and Christian aspects; Rus was to get only the Christian aspect built over Slavic pagan world perception.

One of the factors contributing to adoption in Old Russia of Christianity in its eastern, Byzantine version became availability of Slavic written language. Appearance in Russia of a written language as a method of keeping, processing and disseminating knowledge 
was the first historical prerequisite of the philosophic thought formation. Development of the means of communication ensured improved ways of accumulating and disseminating practical knowledge which had an empirical and a prescribed nature and contained beginnings of some scientific and philosophic knowledge.

Traditionally invention of the Slavic written language is connected with the activities of brothers Constantine (Cyril after going into convent) and Methodios who descended from Thessaloniki. In the ninth century Thessaloniki was a bilingual city whose local population spoke both Greek and Slavic languages. It is possible that Constantine and Methodios could speak Slavonic language (under assumption their mother was Slavonian). Constantine got his education in Constantinople where his teachers were Leo the Mathematician and Patriarch Photios (he was the first man to mention Russia under this name in his speeches). Constantine and Methodios' practices in Slavic lands were sanctioned by both secular and religious authorities of the Byzantine Empire that was specified by political considerations and strategic benefits of the government and the ecclesia which were in a state of close competition with Western Christianity for the influence over barbarian nations. Thus the Slavic education turned up to be a political put-up job of both the Empire and the clergy. The alphabet worked out by Constantine and Methodius was based on Greek letters with addition of a few new letters and was an adaptation of Greek letters to the Slavic language norms and to an early Slavic alphabet - the Glagolitic script which became a frequent practice among South-Western Slavs in the Western Balkans and Moravia. The Cyrillic alphabet which was rather simple in writing had been widely used in secular and religious literature since the ninth century. They commenced to translate liturgical books from the Greek to the Slavic language. Constantine and Methodios were first to translate a number of religious books. The book translation and the permission to administer church services in the native tongue was an alternative to the Western Latin and the Slavic nations' argument in favour of Constantinople and Rome.

Akypon Christianization which allowed administration of church services in native tongues and availability of the Slavic phonetic alphabet, accessibility of a close and well-developed literary language of the Southern Slavs who had been christened before all these factors brought to creation in Russia of conditions for advancement of literature in a perfect language which was understandable to people. The sad fact had contradictory sociocultural consequences. On the one hand we had formation of prerequisites for development of original Russian culture and, first of all, its spiritual component. On the other hand an indirect inclusion of Russia to the Byzantine civilization through the Cyril and Methodios alphabet predetermined narrowness in perception of numerous cultural traditions, first of all the ancient ones. Inasmuch as the Christianity came not with Greek reading and writing, Russia turned out to be separated from the ancient culture which used Greek and Latin languages. Besides “...the influence of the ancient culture and philosophy on the Russian idea was not direct but refracted through the prism of a doctrinal theology which was brought from Byzantium and borrowed from the pagan 
culture only those things which got along with religion and served its circumstantiation". Russia got into the situation of detachment from the classical philosophic ancient heritage which predetermined Russian cultural isolation. Christianity in the Byzantine style and the Old Church Slavonic Cyrillic alphabet made ancient philosophic sources inaccessible for Russia while Western countries had the possibility of becoming familiar with them through the Liturgical Latin. As a result the Western Europe experienced a direct appeal to the ancient culture within the Renaissance and the Russian idea remained to be under the orthodox theological pressure.

In his book The Russian Antiquity: Subject Matter, Role and Destiny of Ancient Heritage in Russian Culture (200o, in Russian) Knabe highlighted specific peculiarities of understanding ancient traditions within the history of Russian culture. According to him the ancient traditions had never been a standing factor in the history of Russian culture, it had never achieved any axiological and world view apprehension. The ancient heritage was not established on its own as an independent axiological system but through the prism of subsequent interpretations only: the Byzantine and later the Western European ones. The attitude to the primary source of this interpretation inevitably determined appraisal of all ancient heritage as such. ${ }^{2}$

In Russia the antiquity was first of all identified with paganism and due to this its value was rejected. Anyhow some information about ancient scientists infiltrated to Russia, which is proven with reference to ancient authors in Russian memorial records. In such a way chronicles reported that some Presbyter Thomas reproached Metropolitan Kliment Smolyatich (1147-1154) that in his zeal "to show himself off as a philosopher" he had resorted to Homer, Plato and Aristotle. ${ }^{3}$ Works of John Damascene (c. 675-749) which had been written under a direct influence Aristotle were translated.

Byzantine monk, Anthony Melissa (in Greek “The Bee”, flourished 11th century), was author of the Collection of teachings and maxims, translated into Slavonic in Kiev in the late twelfth and early thirteenth centuries is of a special interest. The Collection titles $O n$ Wisdom, On Education and Discussion, On Wealth and Meanness, On Sadness and Lack of Sadness, On Compliments, On Envy etc. tell us that in general the Collection referred to matters of morality, codes of conduct and Christian devotion. Each chapter contains about twenty aphorisms. At the beginning of chapters there are aphorisms from the Holy Script and works of Church Fathers; afterwards follow aphorisms belonging or attributed to Old Greek philosophers and writers. The 'Bee' was not only a collection of ethical instructions but also a special encyclopedia of historical knowledge. Historical anecdotes quoted episodes from lives of Philipp the Second Macedonian and Alexander the Great, of Laconian tsars Agesilaos and Leonidas, Athenian statesman Alkibiades, Persian tsars

\footnotetext{
${ }^{1}$ Galaktionov, Nikandrov (1961: 27).

${ }^{2}$ Knabe (2000).

3 Galaktionov, Nikandrov (1961: 25)t.
} 
Darius, Cyrus and others. The Bee became the most prominent source of knowledge about ancient authors' ideas of the medieval Russia. ${ }^{4}$

Similarities and conflicts of interests of the Empire and the ruling elite in Old Russia stipulated inconsistency of the Byzantine influence perception: in some cases they noted its unexacting assimilation and in other cases - its upheaval, conversion and even opposition thereto which was reflected in the Sermon on Law and Grace by Hilarion - the first Metropolite who was not Greek; in creation of the Russian Saints Pantheon; in construction of the Cathedral of St. Sophia and the Golden Gate in Kiev which symbolically competed with the famous structures in Constantinople. "It is highly symptomatic that the Byzantine influence in various spheres of material and spiritual culture of the Old Russia manifested itself with a differential degree of intensity. Sometimes the influence was efficient and amalgamated with local Russian culture, but in other spheres it was more superficial, as if it were like a thin layer over the original Russian culture. As a rule the degree of the Byzantine influence infiltration intensity depended not only on the Byzantine state and church activity but in the first instance on the level of the pre-Christian popular culture in one or another sphere of knowledge by the time the Byzantine influence infiltrated Russia...Moreover some cultural spheres were under temporary domination of Byzantine elements while in other spheres original Russian trends got an obvious advantage". ${ }^{5}$ On the part of the Byzantine Empire the translation of its cultural traditions to Russia had to a considerable degree a purposive character within the context of its general policy in neighbouring barbarian countries. The Byzantine cultural influence should be treated as an active Empire influence with the purpose of bringing Russia under its political and clerical control. From this point of view we can explain selectivity of the translated cultural experience and specificity of its adoption in Russia.

\section{Russian Perception of Byzantine Cultural Heritage after Christianization}

After Christianization the Constantinople and Kiev relations got a special character which allowed Russia to join many spiritual and material achievements in Byzantine culture. At the time Byzantium was the most important cultural and scientific center, so Christianization of Rus promoted adoption of Byzantine handicrafts, arts and philosophy. Anyhow we hardly have any grounds to say that after Christianization Russia started to actively generate new philosophic notions and began an independent development of its philosophy. The Byzantium strategic interests did not include plans of a gratuitous transfer to Russia of its own philosophic, educational and technical experience as well as facilitation of the local philosophy development because it could inevitably lead to strengthening of the Old Russian state and reduction of political and clerical influence

\footnotetext{
${ }^{4}$ Peretz (1919).

5 Udaltsova (1989: 277).
} 
from the Empire's part. Byzantium showed interest to spreading education in Russia only within the scope which contributed to its joining the Byzantine oikumene. That is why translation of the philosophic and educational traditions had a selective and a measured character. It should be taken into account that Russia was also neither materially nor spiritually ready to perceive all the variety of the Byzantine philosophic and technical experience.

We do not have any documentary records stating that the Old Russian state conducted any systematic philosophic research, although it made some independent attempts. When considering the Old Russian philosophic knowledge we cannot but take into account the fact that the available data has a fragmentary character and does not allow compiling a complete picture of it due to the lack of factual evidence.

The Christianization played a key role in introducing Russia to the educational culture. In Old Russian schools they learned grammar and elementary mathematics. Numerous birchbark manuscripts found during archeological excavations in the middle of the twentieth century allow us speaking about a higher proportion of literate people in the Old Russia. Structuring of educational process became one of the first acts of Prince Vladimir after his getting rid of pagan idols. The Tale of Bygone Years (Пов $\mathrm{b} \mathrm{cm}$ времлньныхъ льтъ) read that "He took the children of the best families, and sent them for instruction in book-learning. The mothers of these children wept bitterly over them, for they were not yet strong in faith, but mourned as for the dead" ${ }^{6}$

Nestor the Chronicler wrote about Vladimir's son Yaroslav as follows: "He collected many scriveners and they translated from Greek to Slavic. And they wrote many books which were used for teaching spiritual people who enjoyed the divine learning. Like one man turns up the soil, the other man seeds the fields and people harvest and eat the undepleted food. His Father Vladimir turned up the soil and softened it, that is enlightened it with Christianization. This man seeded hearts of spiritual people with learned words and we are harvesting by accepting the bookish learning.

The advantage of the bookish learning is great; books teach us and lead us on the way to pertinence because we get wisdom and chastity from learned words. These are rivers which water the Universe; they are springs of wisdom. The books are full of immeasurable depth; they pour balm into our wounds in days of sorrow; they are the reigns of chastity. Wisdom is great. Glorifying it Solomon used to say, "I (wisdom) have inculcated counsel; I have summoned reason and prudence. The fear of the Lord is the beginning of wisdom. Mine are counsel, wisdom, constancy, and· strength. Through me kings rule, and the mighty decree justice. Through me are princes magnified and the oppressors possess the earth. I love them that love me, and they who seek me shall find grace".

To some extent these words can be interpreted as Yaroslav's care about creation of his "own, Russian intelligentsia (in all conventionality of the notion in those times)...It needed

\footnotetext{
6 The Russian Primary Chronicle (1953: 117).

7 The Russian Primary Chronicle (1953: 137).
} 
not only literacy. We had to act so that the Kievan Rus would not need any »importation « of Greek clergy, so that it could have its own scientists, writers and philosophers; so that in case of necessity it could wage ideological fights, particularly against the Byzantine imperial ideology".

Kinds of textbooks were the so called Collections. These encyclopedic type collections in a popular form treated various spheres of knowledge: theology, issues of Christian ethics, history, philology, natural science and mathematics. The Collections were translations from Greek and were circulated in Bulgaria in the tenth century, in Russia in the eleventh to thirteenth centuries and even in Moscow State of the fifteenth to the seventeenth centuries. Bulgarian books were widely used and copied in Old Russia. Taking into account the fact that in those times the Old Bulgarian and the Old Russian languages were very close, there was no need to translate the books. But it should be admitted that as of the time of their appearance in Russia most of the books had already been fairly outdated.

Monasteries served as educational centers where knowledge was formed and accumulated and where it was connected with practical life. The education played not so much the cognitive and informational task as the morale building activity. The main educational goal was to show people ways and conditions of spiritual and moral purification and perfection. "For Byzantine literature which was known in Russia in those times the moral and instructive topics were characteristic. It was usual to raise issues related to »everyday virtue and exasperation», »wisdom «, »truth «, »courage and firmness « etc.". ${ }^{9}$ Such peculiarity was a result of the orthodox perception of theology in compliance with the doctrine of the Church Fathers as the way of an experimental knowledge of the God. But unlike Byzantium education in Russia did not become an end in itself and did not serve the purpose of achieving social success. In Russia education was the means of achieving moral and spiritual socialization which was understood in compliance with church requirements and demands. Primacy of aesthetic principles over the philosophic ones became an important trend in Russian culture and determined peculiarities of scientific and educational development.

The Byzantine cultural and political influence was strengthened with the help of ecclesiastic and administrative dependence of the Russian Orthodox Church. Till 1448 the Russian church was a Constantinople Patriarchy Metropolis and Kievan metropolitans were getting approved in Constantinople. Out of 23 metropolitans whose names were mentioned in the pre-Mongolian chronicles, 17 were Greeks. It is not for nothing that when a war conflict had come up between Constantinople and Kiev, Michael Psellos called it not an "aggression" but a Russian "rebellion". The said circumstance testifies to the fact that Byzantines did not take Russia as an independent state. ${ }^{10}$ Anyhow Russian

\footnotetext{
${ }^{8}$ Raushenbach (1989: 198).

9 Galaktionov, Nikandrov (1961: 24).

10 Raushenbach (1989: 199).
} 
affiliation to the Byzantine Christian ecumene as a rightful member was not admitted by Byzantium. In Byzantine political thinking Russia was outside the perfect Christian Universe of romeites. In his Chronographia Michael Psellos describes Tavrian Scythians as barbarians, as if Russia had not adopted Christianity and still remained pagan. ${ }^{11}$ The said fact is partially explained in the research of the dual faith phenomenon which was a system of vision which combined layers of original pagan culture and the ones of the forming Christian and ecclesiastic culture..$^{12}$ In fact many Christians remained pagan and maintained ancient superstitions and traditions while exercising formal churching.

The pagan perception of the religious externality was described in the legend about a choice of religion: "Then we went among the Germans, and saw them performing many ceremonies in their temples; but we beheld no glory there. Then we went on to Greece, and the Greeks led us to the edifices where they worship their God, and we knew not whether we were in heaven or on earth. For on earth there is no such splendor or such beauty, and we are at a loss how to describe it. We know only that God dwells there among men, and their service is fairer than the ceremonies of other nations. For we cannot forget that beauty" ${ }^{13}$

The Kievan Prince Vladimir was choosing religion not by ideology but by the beauty of services - that was his criterion. Christianization ensured that Russia was encultured to Byzantine liturgy, liturgical literature and to the hieratic arts which were relatively easily imposed on the originally mythological world outlook principles of the Slavs. Anyhow translation of spiritual values, philosophy and spiritualistic and ecclesiastic ideology was not noted. The Byzantine Christianity was perceived in the aesthetic and ceremonial form thanks to the beauty of church services and church arts, but the intrinsic meaning of the doctrine remained unobserved.

Priority of moral and artistic conceptualization of genesis over logical analysis which to a considerable degree was characteristic to Byzantium was also connected with the most important role of arts as a way of the World learning. The philosophy was implemented in specific forms which first of all found their ways in icons - the "speculation with paints". The functions which in other religions were performed by abstract thinking, in Russian culture were undertaken by the religious evocation. Emotional and sensuous experience is primarily manifested in logics in intellect. As a result we could denote not a conation to the learning which demanded personal activity and realization of new learning values but to the understanding for which exposure to a general veracity and its application to a personal life was sufficient. Hence originated the idiocy phenomenon and a high status of spiritual hermits who demonstrated religious and moral philosophy ideals by way of their living. The temple synthesis of arts and the orthodox religion which defined speculations with paints prevented the medieval Russian people from model-

\footnotetext{
11 Poppe (1989: 238).

12 Kryanev (1989: 304-314).

13 The Russian Primary Chronicle (1953: 111).
} 
ing their capabilities for abstract-analytic and logical thinking. The liturgical aesthetics affected individuals in such a way that they suppressed the human left hemisphere and inspired the right hemisphere functions. Under such conditions there is no question of availability of favourable prerequisites for the logical philosophic thinking development.

\section{Byzantine Influence on Formation of Philosophic Notions in Muscovy}

The Mongol-Tatar invasion of Russia in the $13^{\text {th }}$ century weakened the ties between Russia and Byzantium, but anyhow the foundation of the Russian cultural singularity had already been laid. Activation of the Byzantine cultural influence took place as far back as in Muscovy after the fall of the Byzantine Empire.

A special role in intellectual revival of the sixteenth century Muscovy played Maxi-

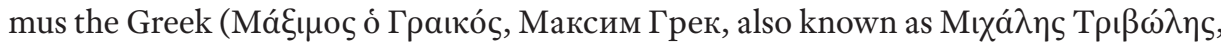
Michael Trivolis, c. 1474-1556). In his youth Michael Trivolis was educated in Italy where he studied ecclesiastic and philosophic literature. Michael was greatly impressed with sermons of Girolamo Savanarolla under whose influence his ecclesiastically ascetic ideals were allegedly formed. After his return from Italy Michael took monastic vows at the Vatopedion Monastery on the Holy Mount of Athos under the name of Maximus. In 1515 the Grand Duke of Moscow Basil the Third asked the Monastery Father Superior to send to Moscow the monk Sabbas to translate church books. But due to Sabbas' anility the monks decided to delegate instead Maximus the Greek. Having arrived in Moscow as a Greek translator he spent the rest of his life in Russia engaged in ecclesiastic and philosophic activities. ${ }^{14}$

Contrary to the vast majority of his Russian contemporaries Maximus the Greek got a systematic philosophic, ecclesiastic and philological education which allowed him reading original works of ancient philosophers whereof he most of all relished Plato, Socrates and Aristotle (although he criticized his doctrine as the one which he considered to be a source of the Catholic scholasticism). In the works of the Church Fathers Maximus the Greek mostly preferred works of Saint Augustine and John Damascene.

Maximus the Greek divided philosophy into "exterior" and "interior" ones. The interior philosophy is directly connected with the orthodox theology and leads to the God perception. The "exterior" philosophy represents the antique wisdom and the Catholic scholasticism which is good only for training correct speech and improvement of thinking, i.e. it can be used within certain limits only.

One of the main topics in the works of Maximus the Greek was abidance by veracity of the orthodox doctrine. He was a convinced follower of the Byzantine orthodoxy and repeatedly wrote about the "Latin faith" badness. In his work On Fortune (O фортуне)

${ }^{14}$ Alexandropoulos (1980). 
he criticized protestant and humanistic understanding of destiny opposing the ideas of the possibility to "conjecture" one's destiny and attempts to modify it of one's own accord.

Maximus the Greek developed Byzantine understanding of secular and ecclesiastic authority relations the basis of which was the idea of social harmony between secular and ecclesiastic authorities. In his messages to Ivan the Fourth Maximus the Greek created an image of the Tsar who established a rightful order in his state and reached harmony of various social strata interests. Full of holy love the Tsar had to rule his subjects with love and with the help of "charitable counselors" without whom he might lapse into the power of passions and evil thoughts. Herewith the role of "charitable counselors" who had to be philosophers was very high in the society. Maximus the Greek wrote, "I think a philosopher but not a fair Tsar to be a creator in this life".

Being ascetic by conviction and dealing with social injustice in Russian socio-political life which was in direct opposition to his Christian ideals, Maximus the Greek commenced criticizing ecclesiastic and secular authorities which resulted in his been indicted of heresy. ${ }^{15}$

Making the Muscovy was attended with industrial production growth, trade development, further accumulation of knowledge about nature and gradual development of rationalistic world view. Translations of works which contributed dissemination of scientific and philosophic knowledge began to appear. The scientific and philosophic information had a utilitarian and an applied value and were of a segmentary and unsystematized character. There were no attempts to build harmonious theoretical systems. Spontaneous development of the pragmatic part of scientific knowledge by the seventeenth century created prerequisites for transfer from the mystic and ecclesiastically-symbolic world perception to a theoretically-rationalistic nature study. In spite of predominance of religious thinking they started to pay specific attention to secular philosophic literature of the West-European Renaissance. The Russian Church tried to suppress introduction of scientific and philosophic knowledge and technologies from western countries which allegedly contributed to spreading heresy and destruction of orthodox traditions. Characteristically the Church initially fought book printing thinking it to be some devilish witchcraft. Only after the Church understood benefits of unification in transferring ecclesiastic texts it approved the book printing about a hundred years after its appearance in the West. Introduction of book printing in Muscovy was not so much technical as a political decision and was under a strict control of the Church.

It was for a good reason that there started a discussion about the stance on Greek and Latin languages, on which language should be taken as a basis for the orthodox school education. In this context Greek and Latin languages represented not only different grammars and lexicons but also different educational systems and world views. The dispute between followers of the "Greek" education and the so called "Latin supporters” (Simeon Polotsky, Симео́н Полоцкий) resulted in the Hellenic supporters’ victo-

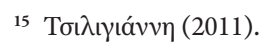


ry. Russia fenced off the "Latin" type of education together with spiritual values of the Renaissance period.

Certain role in this choice played the "Moscow is the Third Rome" ideologeme developed by the Russian Orthodox Church which substantiated the holy mission of the Grand Duke of Moscow (later the Tsar) in defending the orthodox religion. For the first time ever the concept of secular power in Russia (whose supreme mission was preservation of Christianity) was set forth by Philotheus (Филофей, 1465-1542), the Pskov Yeleazarov Monastery starets. The main idea of the "Moscow is the Third Rome" (Москва - Третий Рим) ideologeme lied in the thesis that the Muscovite Russia was the last earthly incarnation of the metaphysical Roman Kingdom: ${ }^{16}$ The Philotheus's theory is represented as a "complete historiosophic concept which introduced us directly to the philosophic sphere" ${ }^{17}$ The idea of a specific messianic purport of Russia turned out to be a leading one through the whole of its further history. Within different historical eras the messianic ideas had been transforming and taking different ideological shapes and colours, but their general trend remained unchanged. The "Moscow is the Third Rome" ideologeme condemned Russia to isolationism, stagnation and authoritarianism. ${ }^{18}$

Attachment of Ukrainian lands to Moscow Tsar which took place after the Treaty of Pereyaslav (Переясла́вская рада) in 1654 was the momentum into development of philosophic ideas, science and education in Muscovy. By that time in Kiev there was an Academy (known as Kyiv-Mohyla Academy, Києво-Могилянська Академія) whose history dated back to the early seventeenth century when the Kiev Metropolia was within the Constantinople Patriarchy jurisdiction. According to its specific nature the Kiev Academy resembled Western European collegiums and many of its teachers got their education in foreign universities.

The Byzantine influence in the Orthodox world "was based exactly on the fact that Byzantium was a cultural center for all orthodox nations of the East wherefrom they all got science, education, the highest and most perfect forms of ecclesiastic and social life, etc. In this respect Moscow looked nothing like the Old Byzantium. It had no idea about sciences and scientific education and even had no schools and persons who got regular scientific education; from the scientific point of view all its educational capital lied in a not very rich and diverse heritage which Russian had got in different times directly or indirectly from Greeks having supplemented it with practically nothing on its part. It is quite natural therefore that the Muscovite priority and superiority in the Orthodox world could be purely superficial and highly conventional". ${ }^{19}$

Trying to assume the Byzantine heir functions Muscovy strived to overpass the ignorance which prevailed in the country so that it could become a source of education for the

\footnotetext{
16 Sinitsyna (1998).

17 Zenkovsky (1948).

18 Florovsky (1991).

19 Knabe (2000).
} 
whole of the Orthodox world. Tsar Alexey Mikhailovich's devotion to educational projects and Greek accomplishments was pretty much explained by the Muscovy Tsar's wish to see himself as an heir of Constantinople Emperors. To some extent some Greeks made concessions to such ideas inasmuch as Muscovy which was growing in strength turned out to be the only orthodox nation which managed to retain its political independence. Political unity demanded uniformity of ceremonies so that is why correction of liturgical texts was an important stage in the massive program of extending Muscovy influence over all the Orthodox nations. In order to assume the Byzantine heir functions Muscovy had to reach the Greek and Russian faith identity. Annexation of Ukraine where the ecclesiastic and ceremonial practices were in line with the Greek ones and differed from the Muscovy practices, promoted the said tendency. It is not for nothing that Ukrainian scientists became the main promoters of Nikon the Patriarch's ecclesiastic innovations.

The discovered differences between Russian ceremonial practices and Greek ones were proclaimed to be heretical. It was declared that the Russian ceremonies had been gradually distorted and strayed from old practices while the Greek ceremonies were closer to the original forms of divine services. Anyhow another point of view was also possible, whereby Muscovy which was on the outskirts of the Orthodox world preserved peculiarities of divine services in the form it had learned in the time of Christianization, whilst the Greek ceremonies had been evolving. The ecclesiastic reforms were painful for Great Russians and as a result they experienced scission which affected the progress of Russian education.

With the purpose of promoting growth of education the Greek brothers Ioannicus (secular name John, 1633-1717) and Sophronius (secular name Spyridon, 1652-1730) Likhuds ( $\Lambda \varepsilon \iota \chi o u ́ \delta \eta \varsigma$ ), natives of the Isle of Cephalonia, came to Moscow under the invitation of Tsar Fedor Alexeyevich. The brothers had been educated in Venice and graduated from the University of Padova. They took direct part in founding in 1685-1687 the Slavonic-Greek-Latin Academy (Славяно-греко-латинская академия) at the Zaikonospassky Monastery. That was the first higher educational establishment in Russia (apart from the Kiev Academy) - a prototype of the Moscow University and the foundation of the Moscow Ecclesiastical Academy. Rules of the Academy founded by the Likhud Brothers stated that it was arranged for people of all statuses and gave its graduates official ranks. There the Likhuds taught mathematics, physics, logics, grammar and eloquence. Later in Novgorod they founded a Slavonic-Greek-Latin School on the model of the Moscow Academy.

The Kiev Academy and the Moscow Slavonic-Greek-Latin Academy were the only educational establishments in Russia where courses of studies presupposed learning mathematics and natural history. Learning Latin language made Western philosophic literature accessible for their graduates. Scholastic practices in the Slavonic-Greek-Latin Academy employed text-books compiled by the Likhud Brothers themselves.

In teaching logics and physics the Likhuds were guided by works of Aristotle complemented with due regard to the latest philosophic developments. In its entirety education at the Academy was in line with the system adopted at the time in the University 
of Padova and other Western European universities. But the Likhuds revaluated and reconsidered western materials from the point of view of orthodox doctrinal statements. Primarily the Academy popularized ecclesiastic education. The main purpose of education was a correct (i.e. orthodox) understanding and interpretation of the Holy Script. The educational institution which had been purposefully established under the order of the State and the Church was incapable of becoming a stronghold of free philosophic ideas. Offices of the Rector and lecturers could be taken only by Greeks and Russians. Students were not allowed to use services of home teachers of foreign languages, to read and keep West European books home. The Academy strictly observed enforcement of these rules and prosecuted persons accused of spreading ideas which contradicted the official Orthodoxy. Guilty parties were subject to tough sentences. As a result instead of a center for education dissemination they established an "ecclesiastic and police-run" educational establishment. In 1694 the Likhud Brothers were removed from the Academy because they were "dandling with physics and philosophy". ${ }^{\circ}$

Anyhow the Likhuds' contribution to the development of Russian science, philosophy and education can hardly be overestimated. The Academy managed to form the first generation of Russian scientists and philosophers. The first scientific work in Russian The Mirror of Natural Vision (Зерцало естествозрительное) - which was a systematic course of Aristotle's Natural Philosophy, appeared under the influence of the Physics compiled by Ioannicus Likhud. Indoctrination to the ancient heritage and first of all to works of Aristotle contributed to establishment of logical reasoning, accumulation of the intellectual materials which formed a further basis for development of Russian science.

In 2007 in recognition of the role of Greek scientists in Russian education development they installed a gift of Greek Government to Moscow City - the Monument to the founders of Slavonic-Greek-Latin Academy, Greek educators, brothers Ioannicus and Sophronius Likhuds (see below):

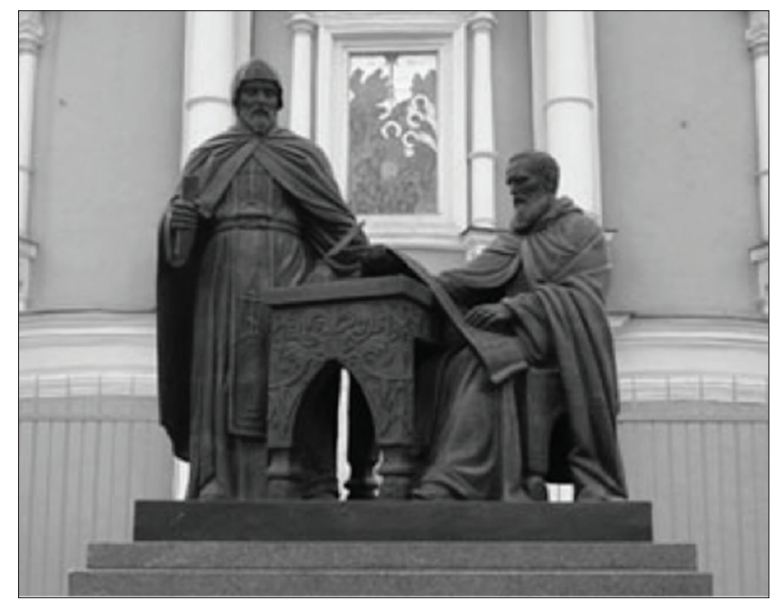

${ }^{20}$ Galaktionov, Nikandrov (1961: 40) 
The Byzantine influence was at the origins of formation and dissemination of philosophic ideas in the medieval Rus and Muscovy. Translation of Byzantine philosophic traditions and their assimilation in Russia specified and determined the original basis of philosophic development in Russia, Ukraine and Byelorussia. Even after weakening and fall of Byzantine Empire the Greek influence continued to be fundamental in the processes of primary formation of philosophic knowledge in Muscovy. A promoter of this influence was the Orthodox Church which specified conditions and specificity of perceiving Byzantine intellectual traditions. The Byzantine influence had a contradictory character and it does not seem possible to univocally assess its manifestations and results. Thanks to Byzantium foundations of Russian philosophy were laid and all its further development cannot be considered without regard to the Byzantine influence. Under the European Renaissance Byzantium had a great secular effect on Western science having laid the foundation of the New Time scientific revolution, but in Russia acquirement of the Byzantine heritage had some other consequences. Specificity of acquiring the Byzantine experience under Russian conditions became a reason of a practical absence of philosophic and natural history investigations and of a long time enmity to development of the forms of logical and analytical thinking. By the end of the seventeenth century the Russian isolationism which was strengthened with the "Moscow is the Third Rome" ideologeme lead to the obvious lagging behind West European countries in scientific and technical spheres. 


\section{BIBLIOGRAPHY}

АлЕКСАНдРоПулос, М., 1980, Сцены из жизни Максима Грека. М.. [Alexandropoulos, М., Scenes from the Life of Maximus the Greek. M.].

ГАлАктионов, А.А., Никандров П. Ф., 1961, История русской философии. М.. [Galaktionov, А.А., Nikandrov, P.F., The History of Russian Philosophy. M.].

ЗЕньковский, В.В., 1948, История русской философии, т. I, Париж. [Zenkovsky, V.V., The History of Russian Philosophy, G.L. Kline (transl.), vol. I, London].

КАПтЕРЕВ, Н.Ф., 1885, Характер отношений России к православному Востоку. М. [Kapterev, N.F., Character of Russian Attitude to the Orthodox East. M.].

Кнабе, Г.С., 2000, Русская античность: Содержание, роль и судьба античного наследия в культуре России. M. [Knabe, G.S., Russian Antiquity: Subject Matter, Role and Destiny of Antique Heritage in Russian Culture. M.].

КРянЕв, Ю.В., ПАвловА, Т.П., 1989, Двоеверие на Руси // Как была крещена Русь. 2-е изд. М. [Kryanev, Y.V., Pavlova, T.P., Dual Faith in Russia // The Way Russia was Christened, 2nd edition. M.].

ПЕРетц, В.Н., 1919, Сведения об античном мире в Древней Руси XI-XIV вв. // Гермес: Научно-популярный вестник древнего и нового мира. Т. 23. [Peretz, V.N., Information about Antique World in Old Russia of the XI-XIV centuries // Hermes: Popular Science Bulletin of the Ancient and the New World, Vol. 23.].

Поппэ, А., 1989, Политический фон крещения Руси (русско-византийские отношения в 986-989 годах) // Как была крещена Русь. 2-е изд. М. [Poppe, A., Political Background of Russian Christianization (Russian-Byzantine Relations in 986-989) // The Way Russia was Christened, 2nd edition. M.].

Рассказы русских летописей. Перевод и составление Михельсон Т.Н.M., 1993. [Stories of Russian Chronicles. Translated and Compiled by Michelson T.N.M.].

РАУшеньах, Б.В., 1989, Сквозь глубъ веков // Как была крещена Русъ. 2-е изд. М. [Raushenbach, B.V., Through the Depth of Centuries // The Way Russia was Christened. 2nd edition. M.].

Синицына, Н.В., 1977, Максим Грек в России, М.: Наука.

Синицына, Н.В., 1998, Третий Рим. Истоки и эволюция русской средневековой концепции (XV-XVI вв). M. [Sinitsyna, N.V., The Third Rome. Beginnings and Evolution of the Medieval Russian Concept (XV-XVI centuries). M.].

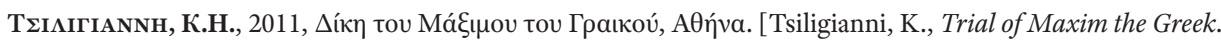
Athens].

УдАльцовА, 3.В., 1989, Киев и Константинополь - культурные связи до 13 в. // Как была крещена Русь. 2-е изд. М., [Udaltsova, Z.V., Kiev and Constantinople - Cultural Relations till the 13-th Century // The Way Russia was Christened. 2nd edition. M.].

Флоровский, г.В., 1991, Пути русского богословия. К. [Florovsky, G.V., Routes of Russian Theology. К.]. Cross, S.H., Sherbowitz-Wetzor, O.P., 1953, The Russian Primary Chronicle, Cambridge.

Dvornik, F., 1962, The Slavs in European History and Civilization, New Brunswick.

Herrin, J., 2008, Byzantium: the Surprising Life of a Medieval Empire, Princeton.

KuCzARA, K., 2012, Grecy w Kościołach wschodnich w Rzeczypospolitej (1585-1621) [Greeks in the Eastern Churches in Rzeczypospolita (1585-1621)], Poznań.

Runciman, S., 1968, The Great Church in Captivity: A Study of the Patriarchate of Constantinople from the Eve of the Turkish Conquest to the Greek War of Independence, Cambridge. 
PA V E L R E V K O - L I N A R D A T O Sociocultural Byzantine Influence on Thought Formation in Medi/ Taganrog/ eval Russia

The Byzantine influence was at the very origins of the formation of various philosophic ideas in the medieval Russia. A major factor responsible for this influence was the Orthodox Church. Thus, it was owing to Byzantium that the foundations of Russian philosophy were laid and all its subsequent developments cannot be properly understood without considering the Byzantine influence.

KEY WOR DS

Byzantine Empire, Medieval Russia, philosophy, education, Orthodox Church. 